\title{
KAJIAN TEMATIS Al-QUR'AN DAN HADITS TENTANG KEPEMIMPINAN
}

\author{
Devi Pramitha \\ Fakultas Ilmu Tarbiyah dan Keguruan UIN MALIKI Malang \\ e-mail: phe2_90@yahoo.co.id
}

\begin{abstract}
Leaders and leadership are two interrelated problems of daily life in society, organization, nation and state. The development level of society, organizations and nations and countries influenced by the leaders and leadership. Islam itself as a religion rahmatan lil 'Alamin also put the issue of leaders and leadership as one of the major issues in his teaching. In the Qur'an and Hadith leadership gets a share of the discussion is not small, many verses of the Koran and the hadiths of the Prophet who Membincang about leadership. In the Islamic concept itself, leadership can be defined as a concept of interaction, relationships, processes of authority, influence activities, directs and coordinates both horizontally and vertically.
\end{abstract}

Keywords: leadership, al-Qur'an, hadith

\begin{abstract}
Abstrak: Pemimpin dan kepemimpinan merupakan dua persoalan keseharian yang saling berkaitan dalam kehidupan bermasyarakat, berorganisasi, berbangsa dan bernegara. Maju dan mundurnya masyarakat, organisasi maupun bangsa dan Negara dipengaruhi oleh para pemimpin dan kepemimpinannya. Islam sendiri sebagai agama rahmatan lil 'alamin juga menempatkan persoalan pemimpin dan kepemimpinan sebagai salah satu persoalan pokok dalam ajarannya. Dalam al-Qur'an dan Hadits kepemimpinan mendapatkan porsi bahasan yang tidak sedikit, banyak ayat-ayat al-Qur'an maupun hadits-hadits Nabi yang membincang tentang kepemimpinan. Dalam konsep Islam sendiri, kepemimpinan dapat diartikan sebagai sebuah konsep interaksi, relasi, proses otoritas, kegiatan mempengaruhi, mengarahkan dan mengkoordinasi baik secara horizontal dan vertikal.
\end{abstract}

Kata-Kata Kunci: kepemimpinan, al-Qur’an, hadits

\section{Pendahuluan}

Secara universal, manusia adalah makhluk Allah yang memiliki potensi kemakhlukan yang paling bagus, mulia, pandai, dan cerdas. Mereka mendapatkan kepercayaan untuk menjalankan dan mengembankan titah-titah amanat-Nya serta memperoleh kasih 
sayang-Nya yang sempurna (al-Banjari, 2008: 21). Hal itu disebabkan karena Allah SWT telah menciptkan manusia sebagai masterpiece dari seluruh ciptaan-Nya. Sampai gelar ahsani taqwim (sebaik-baiknya ciptaan) pun dianugerahkan kepada manusia, sebagaimana yang tertulis pada Surat At-Tin: 4 yang berbunyi:

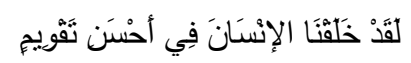

"Telah kami ciptakan manusia dalam bentuk yang sebaik-baiknya"

Sebagai wujud dari ciptaan Allah SWT yang memiliki kesempurnaan, manusia hidup di dunia setidaknya memiliki dua tugas dan tanggung jawab yang besar. Pertama, manusia sebagai seorang hamba ('abdullah) (QS. Adz-Zariyat: 56) yang memiliki kewajiban untuk memperbanyak ibadah kepada Allah sebagai bentuk tanggung jawab 'ubudiyah terhadap Tuhan yang telah menciptakannya. Kedua, manusia sebagai seorang pemimpin (khalifatullah) (QS. Al-Baqarah: 30) yang memiliki jabatan ilahiyah sebagai pengganti Allah dalam mengurus seluruh alam. Dalam artian, manusia sebagai khalifah di muka bumi memiliki kewajiban untuk menciptakan kedamaian, melakukan perbaikan dan tidak membuat kerusakan, baik untuk dirinya maupun untuk makhluk yang lain (QS. Al-A'raf: 56).

Pemimpin dan kepemimpinan merupakan dua persoalan keseharian yang saling berkaitan dalam kehidupan bermasyarakat, berorganisasi, berbangsa dan bernegara. Maju dan mundurnya masyarakat, organisasi maupun bangsa dan Negara dipengaruhi oleh para pemimpin dan kepemimpinannya. Persoalannya adalah beberapa orang berpendapat bahwa kepemimpinan itu tidak dapat dipelajari. Karena menurut mereka kepemimpinan itu adalah suatu bakat yang diperoleh sebagai kemampuan istimewa yang dibawa sejak lahir. Sehingga sebagian orang mengatakan majunya organisasi maupun bangsa dan Negara dipengaruhi oleh keberuntungan seorang yang memiliki bakat alami kepemimpinan yang luar biasa, sehingga ia memiliki kharisma dan kewibawaan sebagai seorang pemimpin.

Namun dalam perkembangannya pemikiran tersebut lambat laun mengalami pergeseran paradigma yang mengatakan bahwa kepemimpinan itu terjadi secara ilmiah bersamaan dengan pertumbuhan seseorang. Seorang ilmuan Frederick W. Taylor pada awal abad ke-20 menjadi pelopor atas pemikiran tersebut yang dikemudian hari kepemimpinan berkembang menjadi satu disiplin ilmu (Kartini, 1998: 47). Islam sendiri sebagai agama rahmatan lil 'alamin juga menempatkan persoalan pemimpin dan kepemimpinan 
sebagai salah satu persoalan pokok dalam ajarannya. Dalam al-Qur'an dan Hadits kepemimpinan mendapatkan porsi bahasan yang tidak sedikit, banyak ayat-ayat al-Qur'an maupun hadits-hadits Nabi yang membincang tentang kepemimpinan.

Begitu pulan halnya dengan kepemimpinan pendidikan, yang dalam hal ini biasa kita sebut dengan kepala sekolah/ madrasah. Kepala sekolah/ madrasah merupakan faktor penggerak, penentu arah kebijakan sekolah/ madrasah yang akan menentukan bagaimana tujuan sekolah/ madrasah dan pendidikan pada umumnya. Kepala sekolah/ madrasah dituntut senantiasa meningkatkan efektifitas kinerja. Melihat penting dan strategisnya posisi kepala sekolah/ madrasah dalam mewujudkan tujuan sekolah, maka seharusnya kepala sekolah/ madrasah harus mempunyai nilai kemampuan public relation yang baik dengan segenap warga di sekolah/ madrasah, sehingga tujuan sekolah/ madrasah dan tujuan pendidikan berhasil dengan optimal. Ibarat nahkoda yang menjalankan sebuah kapal mengarungi samudra, kepala sekolah/ madrasah mengatur segala sesuatu yang ada di sekolah/ madrasah tersebut.

Oleh karena itu mengetahui konsep kepemimpinan dalam perspektif al-Qur'an dan Hadits menjadi salah satu tugas yang sangat penting, sehingga penulis mencoba untuk mengkaji istilah/ tema yang berhubungan dengan kepemimpinan pendidikan, baik yang ada pada ayat-ayat al-Qur'an maupun hadits-hadist Nabi Muhammad SAW dari segi ontologi, epistemologi dan aksiologi.

\section{Ontologi Kepemimpinan}

Menjadi makhluk ciptaan Allah yang paling sempurna membuat manusia memiliki beban berat yang harus ditanggungnya di muka bumi. Tujuan Allah menciptakan manusia beserta kesempurnaanya tidak lain karena manusia pada dasarnya adalah seorang pemimpin atau yang biasa kita sebut dengan istilah khalifatullah fil ardh (wakil Allah SWT di muka bumi), sebagaimana firman Allah dalam al-Qur'an Surat al-Baqarah: 30 yang berbunyi:

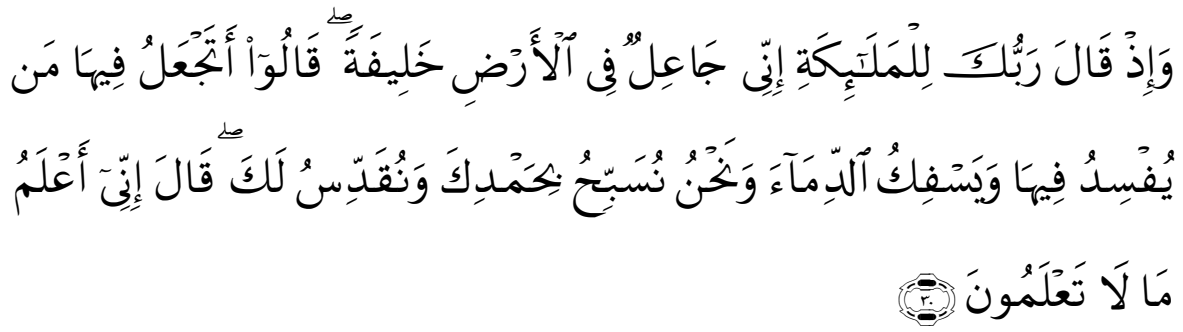


"Dan (ingatlah) ketika Tuhanmu berfirman kepada para Malaikat, "Aku hendak menjadikan khalifah di bumi". Mereka berkata, "Apakah Engkau hendak menjadikan orang yang merusak dan menumpahkan darah di sana, sedangkan kami bertasbih memuji-Mu dan menyucikan nama-Mu?". Dia berfirman, "Sungguh, Aku mengetahui apa yang tidak kamu ketahui."

Ayat tersebut di atas memerintahkan Nabi Muhammad SAW untuk meningat apa yang pernah disampaikan Allah SWT kepada para Malaikat-Nya. Hal ini seklaigus sebuah isyarat bagi Nabi untuk menyampaikan dan mengingatkan kembali umatnya tentang tugas yang pernah dibebankan kepada manusia pada awal penciptaannya. Menurut Muhammad Ali al-Shabuni (1999: 48) dalam kitab tafsirnya Shafwah al-Tafasir: Tafsir li al-Qur'an al-Karim mengatakan bahwa rencana penciptaan dan pengangkatan seorang khalifah di muka bumi yang dimaksudkan untuk menggantikan peran Allah dalam melaksanakan hukum-hukum-Nya adalah Nabi Adam a.s dan juga kaum-kaum sesudahnya yang sebagian menggantikan sebagian lainnya dalam kurun waktu dan generasi yang berbeda.

M. Quraish Shihab (172-173) dalam Tafsir al-Misbah juga menjelaskan makna khalifah sebagai yang menggantikan atau yang datang sesudah siapa yang datang sebelumnya. Atas dasar ini, ada yang memahami kata khalifah berarti yang menggantikan Allah dalam menegakkan kehendak-Nya dan menerapkan ketetapan-ketetapanNya, tetapi hal ini bukan brerarti karena Allah tidak mampu atau menjadikan manusia berkedudukan sebagai Tuhan, namun lebih karena Allah bermaksud menguji manusia dan memberinya penghormatan.

Sehingga dari ayat diatas terlihat bahwa Allah memakai istilah khalifah yang sangat erat kaitannya dengan kepemimpinan. Oleh karena itu, persoalan kepemimpinan sejatinya telah ada sejak penciptaan manusia masih dalam rencana Allah SWT. Ayat ini mengisyaratkan bahwa khalifah (pemimpin) adalah pemegang mandat Allah SWT untuk mengemban amanah dan kepemimpinana langit di muka bumi.

Karena manusia terlahir sebagai khalifah fil ardh, maka tugas selanjutnya adalah menggali potensi kepemimpinannya yang bertujuan memberikan pelayanan serta pengabdian yang diniatkan semata-mata karena amanah Allah, yaitu dengan cara memainkan perannya sebagai pembawa rahmat bagi alam semesta (Tasmara: 
163). Oleh karena itu kepemimpinan bagi semua manusia bukanlah pilihan, melainkan sebagai suatu keharusan karena dengan takdirnya manusia telah diberi amanah sebagai seorang pemimpin. Seorang presiden menjadi pemimpin bagi rakyatnya, seorang direktur menjadi pemimpin bagi staff dan karyawannya, seorang ketua menjadi pemimpin anggotanya, seorang guru menjadi pemimpin bagi muridmuridnya, seorang ayah menjadi pemimpin bagi keluarganta, bahkan setiap manusia menjadi pemimpin bagi dirinya sendiri.

Dalam konsep Islam sendiri, kepemimpinan dapat diartikan sebagai sebuah konsep interaksi, relasi, proses otoritas, kegiatan mempengaruhi, mengarahkan dan mengkoordinasi baik secara horizontal dan vertikal. Yang kemudian dalam teori manajemen, fungsi pemimpin sebagai perencana dan pengambil keputusan (planning and decision maker), pengorganisasi (organization), kepemimpinan dan motivasi (leading and motivation), pengawasan (controlling), dan lainlain (Fakih dkk., 2001: 3-4). Dalam al-Qur'an Surat Shad: 26 Allah SWT berfirman:

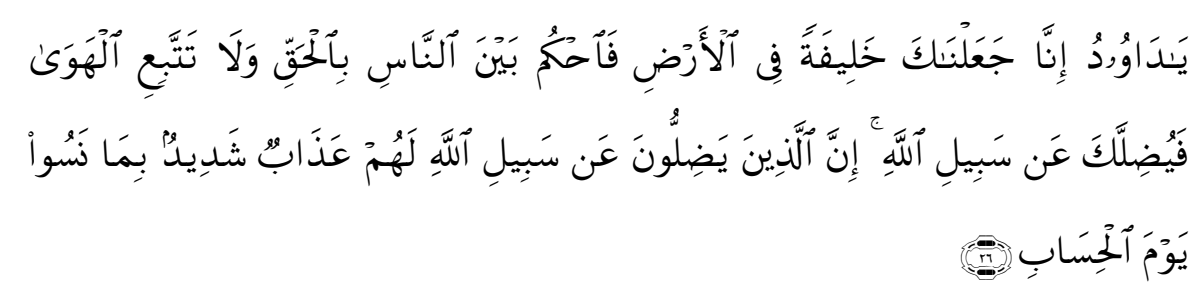

"(Allah berfirman), "Wahai Dawud! Sesungguhnya engkau Kami jadikan khalifah (penguasa) di bumi, maka berilah keputusan (perkara) di antara manusia dengan adil dan janganlah engkau mengikuti hawa nafsu, karena akan menyesatkan engkau dari jalan Allah. Sungguh, orang-orang yang sesat dari jalan Allah akan mendapat azab yang berat, karena mereka melupakan hari perhitungan."

Ayat tersebut mengisyaratkan bahwa salah satu tugas dan kewajiban utama seorang khalifah adalah menegakkan supremasi hukum secara al-Haq. Seorang pemimpin tidak boleh menjalankan kepemimpinannya dengan mengikuti hawa nafsu. Karena tugas kepemimpinan adalah tugas fi sabilillah dan kedudukannyapun sangat mulia. Sehingga dapat disimpulkan bahwa kepemimpinan dalam perspektif Islam adalah suatu kegiatan atau kemampuan orang lain untuk mengarahkan dan memotivasi tingkah laku orang lain, serta ada 
usaha kerja sama yang sesuai dengan nilai-nilai Al-Qur'an dan AlHadits untuk mencapai tujuan yang diinginkan bersama.

Ada beberapa term yang sudah lazim dipakai dalam khazanah Islam dalam hal kepemimpinan, yaitu: khalifah, ulul amri, imam dan malik. Khalifah sebagaimana didefinisikan oleh Ibnu Khaldun memiliki dua tuntutan kemaslahatan dunia dan akhirat. Dalam satu sisi, pemimpin merupakan pengganti kepemimpinan yang mendapat mandate dari langit setelah Rasul tiada. Sedangkan pada sisi yang lain, pemimpin mengatur manusia di bumi yang barang tentu rasionalitas pemimpin harus berjalan dengan kondisi objektif di bumi (Baharuddin dan Umiarso, 2012: 82).

Istilah ulul amri dapat diartikan sebagai pemilik kekuasaan dan pemilik hak untuk memerintahkan sesuatu. Seseorang yang memiliki kekuasaan untuk memerintahkan sesuatu berarti yang bersangkutan memiliki kekuasaan untuk mengatur dan mengendalikan keadaan (Salim, 2004: 231). Di dalam al-Qur'an Surat An-Nisa': 83 mengidentifikasi akan eksistensi kepemimpinan yang sangat terkait dengan kepemimpinan Tuhan dan Rasul-Nya sehingga setelah Nabi wafat maka ulil amri sebagai rujukan dalam menghadapi masalah serta menjadi kewajiban untuk selalu ditaati.

Selanjutnya, kata imam yang berakar dari huruf hamzah dan mim, kedua huruf tersebut mempunyai banyak arti, diantaranya ialah pokok, tempat kembali, jama'ah, waktu dan maksud (Zakariyya, 1989: 21). Para ulama mendefinisikan kata imam sebagai setiap orang yang dapat diikuti dan ditampilkan ke depan dalam berbagai permasalahan. Sedangkan untuk term al-Malik bermakna seseorang yang mempunyai kewenangan untuk memerintahkan sesuatu dan melarang sesuatu dalam kaitan dengan sebuah pemerintahan (Zakariyya, 1989: 351).

Sehingga inti dari pada term-term kepemimpinan di atas mengandung persamaan pada ranah menuntun atau memobilisasi sejumlah manusia untuk mencapai tujuan bersama yang diridhai oleh Allah SWT. Artinya, term-term tersebut bermuara pada pengabdian manusia terhadap Sang Pencipta-nya dalam menggapai kebahagiaan dunia dan akhirat. Dalam hal ini, Islam mengarahkan kepemimpinan pada prinsip-prinsip kepemimpinan Islam, yaitu amanah, adil, syura (musyawarah), dan amr ma'ruf nahi munkar yang harus diaplikasikan dalam perilaku kepemimpinan.

Dalam keterangan yang lain (Rivai dan Arifin, 2009: 136) disebutkan salah satu prinsip kepemimpinan Islami adalah: Pertama, 
berpegang teguh amanah sebagaimana ditegaskan dalam Surat Al-Hajj Ayat 41:

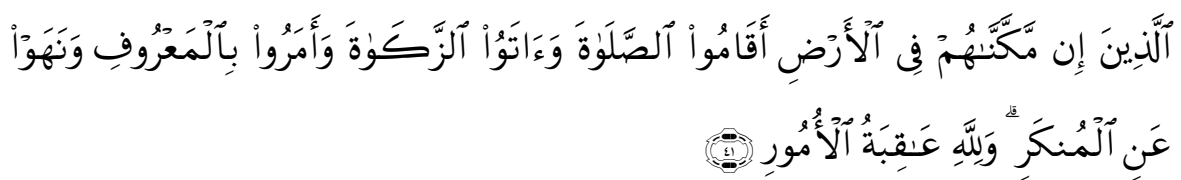

"(Yaitu) orang-orang yang jika Kami beri kedudukan di bumi, mereka melaksanakan shalat, menunaikan zakat, dan menyuruh berbuat yang makruf dan mencegah dari yang mungkar; dan kepada Allah-lah kembali segala urusan".

Kedua, melaksanakan amar al-makruf dan nahyu al-munkar sebagaimana dalam Surat Ali Imran ayat 110:

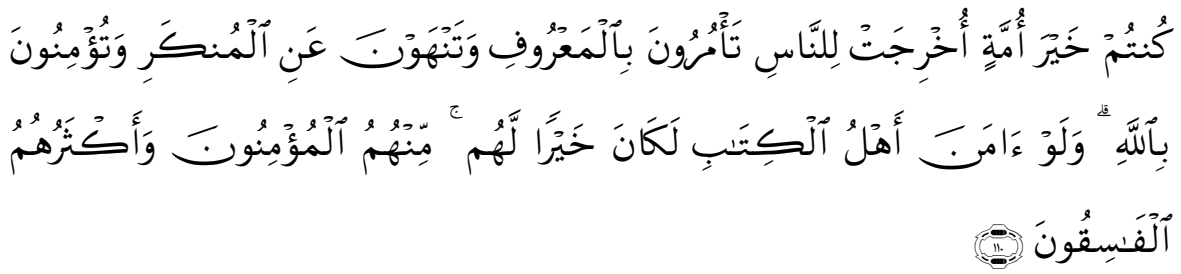

"Kamu (umat Islam) adalah umat yang terbaik yang dilahirkan untuk manusia, (karena kamu) menyuruh (berbuat) yang makruf, dan mencegah dari yang mungkar, dan beriman kepada Allah. Sekiranya Ahli Kitab beriman, tentulah itu lebih baik bagi mereka. Di antara mereka ada yang beriman, namun kebanyakan mereka adalah orang-orang fasik".

Sehingga berpijak dari kedua ayat di atas bahwa prinsip yang harus dipegang oleh seorang pemimpin dalam pandangan al-Qur'an adalah pemimpin harus berpegang teguh pada amanah yang diembannya dan juga senantian ber-amar ma'ruf nahi munkar.

\section{Epistemologi Kepemimpinan}

Islam adalah agama sekaligus sebagai sebuah sistem kehidupan (Way of Life), yaitu sistem yang menggabungkan antara ibadah dan siyasah politik), karena peranannya dalam kehidupan manusia bukan sekedar untuk memberi petunjuk saja, tetapi juga untuk memberikan pengaruh dan mengaplikasikan ajaran-ajarannya dalam semua aspek kehidupan manusia. Seorang muslim tidak dapat mengatur 
kehidupannya sesuai dengan aturan Islam kecuali jika ada masyarakat yang menaunginya, pemimpin yang melindunginya sehingga terjaminlah keamanan diri dan agamanya. Itulah sebabnya kepemimpinan dalam Islam merupakan prinsip yang sangat penting dan mendasar bahkan dianggap sebagai kewajiban.

Ada ungkapan yang menyatakan bahwa agama adalah asas sedangkan kekuasaan adalah penjaga, sesuatu yang tidak mempunyai asas akan runtuh dan yang tidak mempunyai penjaga akan hilang. Ungkapan yang masyhur menyebutkan:

$$
\text { إن الـاله يـزع بالســــان مـالا يز ع بالقـر آن }
$$

"Sesunggunya Allah mencegah dengan kekuatan penguasa, apa yang tidak dapat dicegah dengan al Qur'an".

Maksudnya bahwa pelanggaran dan penyimpangan yang dilakukan oleh manusia tidak dapat dikontrol dan diawasi melainkan dengan kekuasaan, sedangkan al-Qur'an merupakan konsep undangundang yang membutuhkan penetapan hukum dan penerapan (enforcement of the law) oleh pihak pemerintah. Oleh sebab itu kepemimpinan dalam kehidupan masyarakat merupakan kebutuhan yang diwajibkan oleh Islam, karena peranan agama dalam kehidupan manusia bukan sebatas memberi petunjuk untuk meluruskan aqidah, tetapi juga berfungsi untuk mengatur kehidupan mereka sesuai dengan manhaj Allah dan syariat-Nya.

Hal ini tidak mungkin dapat terwujud tanpa adanya kekuasaan yang menjalankan hukum-hukum syariat dalam kehidupan manusia. Setiap Nabi dan rasul yang diutus oleh Allah S.W.T. kepada ummat manusia telah diberikan manhaj dan syariat untuk dilaksanakan dan bukan sekedar dibaca dan dipelajari saja. Ini berarti bahwa tegaknya kepemimpinan dan pemerintahan termasuk tugas para nabi dan rasul dalam rangka memudahkan terlaksananya hukum dan syariat Allah S.W.T. Allah Subhanahu wa Ta'ala berfirman:

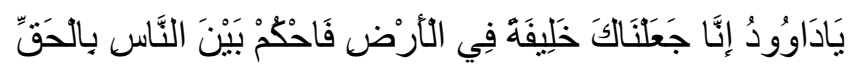

"Wahai Daud, sesungguhnya Kami menjadikan kamu khalifah (penguasa) di muka bumi, maka berilah keputusan (perkara) di antara manusia dengan adil." 
Islam sebagai risalah terakhir dan syariat yang sempurna, tidak mungkin dapat terwujud tanpa disertai dengan tegaknya prinsipprinsip atau dasar-dasar negara yang akan mewujudkan tujuan ajaran Islam ini melalui pelaksanaan undang-undang di kalangan umat manusia. Allah SWT berfirman:

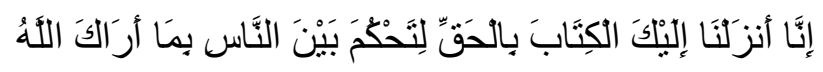

"Sesungguhnya Kami telah menurunkan Kitab kepadamu (wahai Muhammad) dengan membawa kebenaran, supaya engkau mengadili di antara manusia dengan apa yang telah Allah wahyukan kepadamu".

Pemerintahan (government) dan kepemimpinan bagi suatu umat (masyarakat) sangat penting karena merupakan fitrah dan tuntutan kehidupan sosial umat manusia. Hal ini telah dipahami oleh Rusulullah s.a.w. bahkan tanpa membatasi pentingnya kepemimpinan pada komunitas yang besar saja tetapi juga dalam komunitas yang kecil. Dari Abu Hurairah Rasulullah s.a.w. bersabda:

$$
\text { إذا خـرج ثلاثة فى سفر فليؤمّروا أحدهـم }
$$

"Apabila tiga orang dalam perjalanan maka hendaklah mereka mengangkat salah seorang di antara mereka sebagai pemimpin".

Dengan demikian, sangat jelas bahwa kepemimpinan dalam kehidupan bermasyarakat harus terwujud. Imam al Mawardi menyatakan dalam kitabnya al-Ahkām al-Sultāniyah: "Lembaga kepala negara dan pemerintahan diadakan sebagai pengganti fungsi kenabian dalam menjaga agama dan mengatur kehidupan dunia. Pengangkatan kepala negara untuk memimpin umat Islam adalah wajib menurut ijma' (consensus)." Dalam konteks ini menurut Ibnu Taimiyah, mengatur urusan umat manusia termasuk kewajiban agama yang besar, bahkan tidak mungkin agama dan dunia dapat ditegakkan jika tidak ada pemerintahan. Sesungguhnya kemaslahatan manusia tidak mungkin dicapai kecuali mereka hidup bermasyarakat, dalam masyarakat itu mereka saling membutuhkan antara satu dengan yang lain sehingga membutuhkan seorang pemimpin.

Dalam masalah yang sama Ibnu Khaldun menyatakan: "Pengangkatan imam (pemimpin) adalah wajib, kewajiban tersebut berdasarkan ijma' para sahabat dan tabi'in. Karena ketika Rasulullah s.a.w. wafat, para sahabat beliau segera membaiat Abu Bakar (r.a.) dan 
menyerahkan segala urusan mereka kepadanya. Demikian pula pada setiap zaman setelahnya, umat Islam tidak pernah dibiarkan dalam ketidakaturan pada suatu masa. Hal ini telah menjadi ijma' yang menunjukkan wajibnya mengangkat pemimpin".

\section{Aksiologi Kepemimpinan}

Dalam kehidupan bermasyarakat yang mengenal peradaban, selalu ada suatu komunitas yang di dalamnya harus terdapat seorang pemimpin dan orang-orang yang dipimpin. Namun, faktanya sering kali dalam hal kepemimpinan menimbulkan permasalahan tersendiri terutama pada aspek kriteria seorang pemimpin. Pertanyaan yang kemudian sering muncul adalah bagaimana mendapatkan seorang calon pemimpin yang sadar akan posisinya sebagai pemimpin yang memiliki makna bahwa pemimpin itu adalah pelayan bagi orang-orang yang dipimpinnya.

Beberapa hadits Nabi pun kemudian menjelaskan tentang syarat-syarat mutlak yang harus dimiliki oleh seorang pemimpin yang betul-betul berkualitas. Gambaran hadits Nabi tentang kriteria kepemimpinan antara lain sebagai berikut:

1. Memiliki Jiwa Kepemimpinan

Sebuah hadits yang diriwayatkan oleh Ahmad bin Hanbal (1419 H./ 1998 M.: 183) dengan tegas menjelaskan tentang jiwa kepemimpinan yang harus dimiliki oleh seorang pemimpin, yaitu:

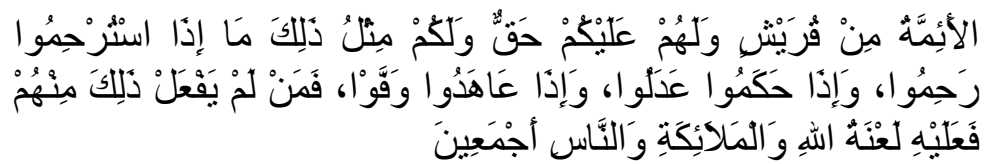

"Para pemimpin itu adalah dari suku Quraisy. Sesungguhnya mereka mempunyai hak atas kamu dan kamu juga mempunyai hak yang sama atas mereka, selagi mereka diminta mengasihi, maka mereka akan mengasihi, jika berjanji mereka akan menepati (janji itu) dan jika menghukum mereka berlaku adil. Maka barang siapa di antara mereka yang tidak berbuat hal yang demikian, maka laknat Allah, malaikat dan manusia seluruh atas mereka".

Secara lahiriah hadits diatas memang mengatakan bahwa kepemimpinan harus dipegang orang-orang Quraisy, bahkan jika ada orang yang meyakini kebolehan 
kepemimpinan di luar suku Quraisy, ia termasuk orang yang sesat dan keluar dari kelompok yang selamat. Namun kemudian konsepsi kepemimpinan ini pada akhirnya dikritik habis oleh Ibnu Khaldun. Menurutnya kepemimpinan Quraisy tidak berarti harus dari suku Quraisy tetapi pada karakteristik kepemimpinan Quraisy yang kharismatik, tegas dan tangguh. Sehingga pokok persoalan kepemimpinan bukan pada orangorang Quraisy, tetapi pada sifat dan karakter yang memungkinkan seseorang layak untuk menjadi pemimpin sesuai dengan karakter yang dimiliki oleh suku Quraisy pada saat itu (al-Qaradawi, 2000: 24).

Suku Quraisy sudah dikenal sejak dulu sebagai orang yang paling maju dan sangat dermawan pada zamannya di bangsa Arab. Hal itu disebabkan karena mereka sudah melakukan perjalanan yang jauh untuk berdagang sehingga mereka memiliki koneksi yang kuat, begitu pula dengan pengetahuan tentang daerah-daerah sekitarnya, serta penguasaan terhadap administrasi birokrasi pada saat itu karena pasti mereka akan berinteraksi pula dengan raja atau pemuka kerajaan. Sehingga selain karakter yang disebutkan dalam hadits di atas, mereka juga unggul dari suku-suku yang ada saat itu seperti kecakapan berafiliasi, mobilisasi massa yang baik, ekonom handal, dan berbudi pekerti yang santun.

2. Profesional

Kepemimpinan dan jabatan bukanlah suatu keistimewaan, melainkan suatu tanggung jawab yang harus dilaksanakan oleh seorang pemimpin. Sehingga sekalipun ia seorang pemimpin tidak boleh bertindak secara sewenang-wenang melainkan kewenangan yang ia miliki harus digunakan untuk melayani anggota/ bawahannya. Karena kepemimpinan tersebut merupakan amanah maka sebaiknya yang pantas untuk mengembannya adalah orang yang cakap dibidangnya. Oleh sebab itu, Rasulullah SAW melarang orang yang tidak cakap untuk memangku jabatan karena nantinya ia tidak akan mampu mengemban tugas tersebut dengan semestinya. Sabda Nabi Muhammad SAW (al-Bukhari, 1987):

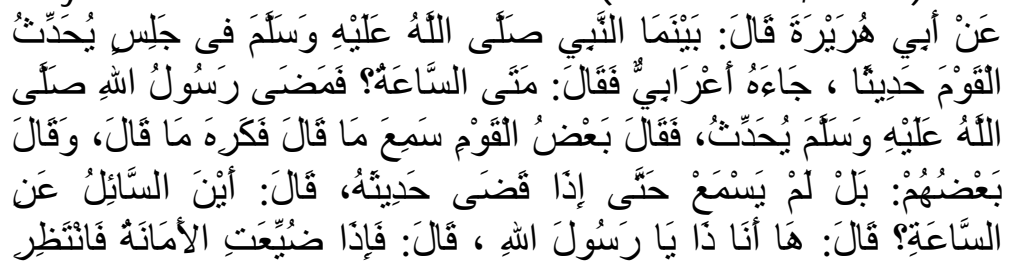




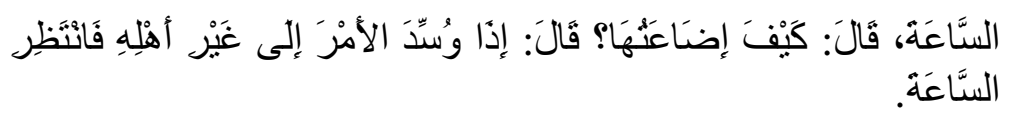

"Dari Abu Hurairah berkata, ketika Rasulullah sedang memberikan pengajian dalam suatu majelis, datanglah seorang pedalaman seraya bertanya "Kapan hari kiamat?" akan tetapi Rasulullah tetap melanjutkan pengajiannya, sebagian hadirin berkata bahwa Rasulullah mendengar pertanyaannya akan tetapi tidak suka. Sebagian yang lain berkata bahwa Rasulullah tidak mendengarnya. Setelah Rasulullah selesai pengajian, beliau bertanya "Mana orang yang bertanya tentang hari kiamat?" Saya wahai Rasulullah, lalu beliau menjawab "Jika amanah sudah disiasiakan, maka tunggulah hari kiamat", orang tersebut bertanya lagi "Bagaimana menyia-nyiakan amanah" Rasulullah menjawab "Apabila suatu urusan diserahkan kepada orang yang bukan ahlinya, maka tunggulah Kiamat."

Untuk mengungkap kandungan hadis di atas, maka perlu mengkaji apa yang dimaksud dengan الساعة daير أهله,الأمر dand Rauf dalam kitab syarahnya menjelaskan bahwa yang dimaksud dengan الأمر adalah segala sesuatu yang terkait dengan agama seperti pemerintahan, kehakiman, fatwa dan pengajaran serta yang lain-lain (al-Manawi, 1994: 578). Sementara yang dimaksud dengan غير أهله adalah orang-orang yang fasik, penyeleweng dan bukan keturunan baik-baik (tidak punya pengaruh dalam masyarakat) (al-Manawi, 1988: 264). Sedangkan الساعة bukannya diartikan sebagai hari kiamat, akan tetapi itu bisa jadi merupakan perumpamaan tentang sebuah kehancuran, kecarut-marutan, kebodohan yang merajalela, kelemahan Islam, ketidakmampuan orang-orang yang professional dan kompoten untuk menegakkan kebenaran dan merealisasikannnya dalam kehidupan dunia, laksana hari kiamat yang dahsyat (al-Manawi, 1994: 578). Sedangkan menurut Mushthafa al-Gulayaini (t.t.,: 35), hadis di atas mengisyaratkan bahwa jika urusan diserahkan pada bukan ahlinya, maka tunggulah saat kegagalan dan kerusakannya.

Dari penjelasan teks di atas maka dapat penulis tarik kesimpulan bahwa dalam hadits ini jika suatu pekerjaan, jabatan, terlebih lagi urusan agama diserahkan kepada orang yang tidak amanah dan tidak bertanggung jawab maka akan 
terjadi kekacauan, ketidakadilan bahkan kehancuran. Sehingga hadits diatas menekankan pada nilai profesionalisme yang harus dimiliki oleh seorang pemimpin.

\section{Mampu Melaksanakan Tugas}

Menjadi seorang pemimpin harus selalu bersedia melaksanakan hukum yang telah ditetapkan dan juga tugas yang diembankan kepadanya kapanpun dan bagaimanapun kondisinya. Sehingga menjadi seorang pemimpin dituntut harus memiliki kesehatan jasmani dan rohani, seperti yang dijelaskan pada hadits Nabi di bawah ini (al-Hajjaj, 2001: 6):

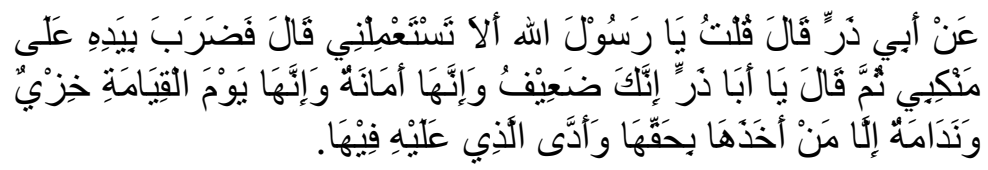

Dari Abu Zar, "Saya berkata kepada Rasulullah, wahai Rasulullah tidakkah engkau mengangkatku menjadi pejabat, lalu Rasulullah menepuk pundaknya seraya berkata "wahai Abu Zarr, sesungguhnya engkau lemah, sedangkan jabatan itu adalah amanah dan merupakan kehinaan serta penyelasan pada hari kiamat nanti kecuali bagi orang yang mendapatkannya dengan hak serta melaksanakannya dengan baik dan benar".

Untuk mendapatkan makna yang baik penulis menganggap perlu menjebarkan kosa kata ضعيف dalam hadis ini, kata tersebut yang dalam kamus bahasa Indonesia yang berarti lemah, sedangkan dalam bahasa Arab memberikan arti kata ini merupakan lawan dari kuat, sedangkan menurut ulama Bashra bahwa arti dari lafazd tersebut bisa digunakan dalam arti lemah secara fisik maupun lemah secara mental/ kecerdasan (al-Misri, t.t.: 203).

Al-Nawawi (1392 H.: 210) berkata ketika mengomentari hadis Abu Zarr: "Hadis ini merupakan pokok yang agung untuk menjauhi kepemimpinan terlebih lagi bagi seseorang yang lemah untuk menunaikan tugas-tugas kepemimpinan tersebut. Adapun kehinaan dan penyesalan akan diperoleh bagi orang yang menjadi pemimpin sementara ia tidak pantas dengan kedudukan tersebut atau ia mungkin pantas namun tidak berlaku adil dalam 
menjalankan tugasnya. Maka Allah menghinakannya pada hari kiamat, membuka kejelekannya dan ia akan menyesal atas kesiasiaan yang dilakukannya.

Dari penjelasan hadits di atas, maka dapat disimpulkan bahwa ketika seseorang ingin mengajukan diri untuk menjadi seorang pemimpin itu bukanlah sesuatu yang tercela jika tidak dibarengi dengan kelayakan diri menjadi pemimpin. Begitupun jika seseorang diangkat menjadi pemimpin karena dukungan atau permintaan umat, memenuhi syarat dan mampu menjalankan tugas dengan amanah maka yang seperti ini juga tidaklah tercela.

4. Sesuai dengan Aspirasi Rakyat

Suatu kepemimpinan Negara akan terlaksana ketika ada ikatan antara rakyat dan pemimpinnya, biasanya yang mewakili rakyat adalah anggota Dewan Perwakilan Rakyat baik di tataran pusat, provinsi maupun daerah. Aspirasi dari rakyat dalam proses kepemimpinan sangat dibutuhkan karena dalam setiap pengambilan keputusan maupun menentukan peraturan harus melibatkan banyak komponen, salah satunya adalah rakyat itu sendiri. Sehingga nantinya akan terjalin suasana yang harmonis antara pemimpin dan rakyatnya karena saling memahami kewajiban dan hak masing-masing, seperti yang tergambar dalam hadist Nabi di bawah ini (al-Hajjaj, 2001: 1481):

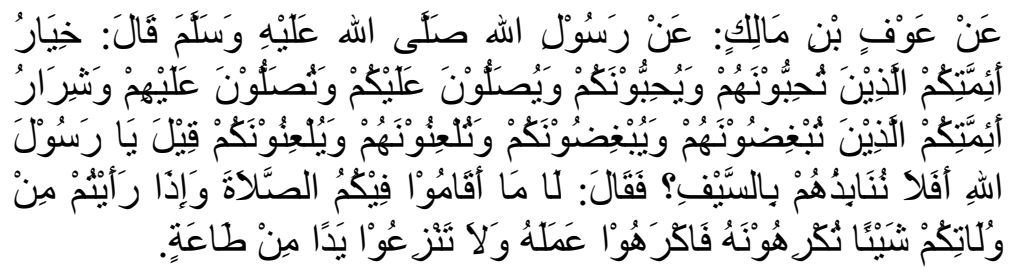

"Dari 'Auf ibn Malik, dari Rasul saw. Bersabda "sebaik-baik pemimpin kalian adalah orang yang mencintai kalian begitu pula sebaliknya dan mereka selalu mendoakan kalian dan kalian juga selalu mendoakan mereka, dan sejela-jeleknya pemimpin kalian adalah yang kalian benci dan mereka juga membenci kalian dan kalian melaknat mereka begitu pula sebaliknya, Rasul ditanya: apakah mereka boleh diperengi? Rasul menjawab tidak selama masih mengerjakan shalat dan jika kalian melihat pada diri mereka sesuatu yang tidak disukai maka bencilah pekerjaannya dan membangkang/tidak patuh". 
Hadis di atas menuntut adanya keserasian atau kerjasama yang baik antara pemimpin dan yang dipimpin, semua itu dapat terwujud dengan diangkatnya pemimpin yang dapat diterima oleh masyarakat karena pemimpin merupakan representase dari suara rakyat sehingga tidak berlebihan bila sebuah kalimat yang sering digunakan dalam menggambarkan keagungan aspirasi rakyat tersebut dengan ungkapan "suara rakyat adalah suara Tuhan" walaupun ungkapan ini masih perlu direnungkan ulang.

Dalam hadis ini pula terlihat Nabi memposisikan pemimpin sebagai orang yang mulia sehingga dilarang untuk dicaci, laknat dan membunuhnya, akan tetapi Rasul tidak melarang ummatnya agar ditetap kritis.

5. Musyawarah

Pemilihan dan pengangkatan seorang pemimpin hendaknya merupakan hasil musyawarah/ kesepakatan mayoritas masyarakat. Dalam kepemimpinan, musyawarah itu sendiri biasanya disebut demokrasi yang artinya melibatkan suara masyarakat agar dapat berpartisipasi dalam pemilihan seorang pemimpin atau dengan sistem keterwakilan, dan lain sebagainya. Rasulullah tidak pernah menentukan mekanisme pengangkatan seorang pemimpin secara eksplisit, namun gambaran tentang musyawarah banyak terdapat di dalam ayat-ayat al-Qur'an dan hadits, sebagaimana hadits di bawah ini (al-Hajjaj, 2001: 1454):

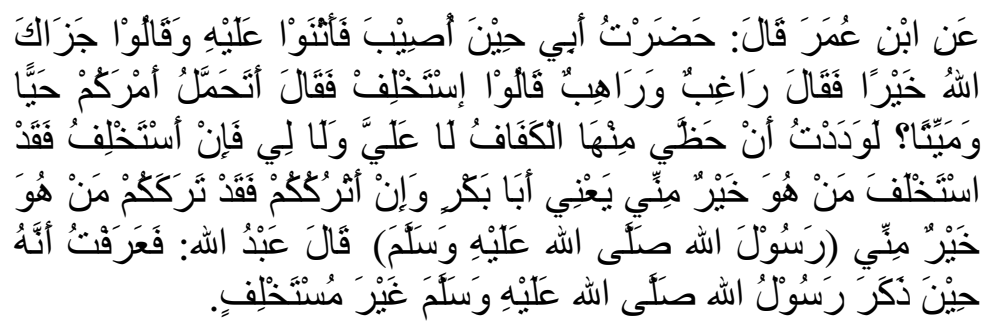

"Dari Ibn 'Umar berkata: saya berada bersama ayahku ketika dia terluka, kemudian orang berdatangan seraya berkata "semoga Allah membalas kebaikanmu", 'Umar berkata "samasama", lalu orang yang hadir berkata "angkatlah calon penggantimu", maka dia berkata "apakah saya harus menanggung urusanmu dunia akhirat? Saya tidak ingin keputusanku merugikan bagiku dan tidak pula menguntungkanku, maka jika saya mengangkat pengganti maka orang yang lebih mulia dari saya telah melakukannya (Abu Bakar) dan jika saya tidak melakukannya 
atau mendiamkannya maka sungguh itu telah dilakukan oleh orang yang lebih mulia dariku yakni Rasulullah”, Ibn 'Umar berkata: maka sejak saat itu saya mengetahui bahwa Rasulullah tidak akan menentukan penggantinya".

Pada hadits di atas pada prinsipnya menggambarkan suasana pasca ditikamnya khalifah 'Umar ibn al-Khattab, pada saat itu orang yang datang menjenguk meminta 'Umar berwasiat untuk menunjuk penggantinya pasca kepergiannya nanti, akan tetapi 'Umar menolak karena menurutnya Rasululllah tidak melakukan penunjukan secara langsung akan tetapi membiarkan masyarakat yang menentukannya. Dengan demikian, dapat dipahami bahwa 'Umar menginginkan pemilihan dan pengangkatan khalifah baru dengan cara musyawarah.

\section{Kesimpulan}

Berdasarkan latar belakang, rumusan masalah, dan pembahasan di atas, maka dapat ditarik kesimpulan sebagai berikut:

1. Kepemimpinan dalam perspektif al-Qur'an telah ada sejak penciptaan manusia masih dalam rencana Allah SWT. Sehingga manusia yang di ciptakan di muka bumi sejatinya adalah seorang pemimpin atau yang biasa disebut dengan khalifahtullah fil ard yaitu pemegang mandat Allah SWT untuk mengemban amanah dan kepemimpinana langit di muka bumi. Sehingga salah satu tugas dan kewajiban utama seorang khalifah dalam perspektif al-Qur'an adalah menegakkan supremasi hukum secara al-Haq.

2. Kepemimpinan dalam kehidupan masyarakat merupakan kebutuhan yang diwajibkan oleh Islam, karena peranan agama dalam kehidupan manusia bukan sebatas memberi petunjuk untuk meluruskan aqidah, tetapi juga berfungsi untuk mengatur kehidupan mereka sesuai dengan manhaj Allah dan syariat-Nya.

3. Kriteria kepemimpinan yang ideal berdasarkan hadis-hadis Nabi Muhammad SAW paling tidak memenuhi 5 unsur, yaitu: (1) seorang pemimpin memiliki jiwa kepemimpinan yang seperti jiwa suku Quraisy yaitu kharismatik, tegas dan tangguh; (2) professional dalam artian seorang pemimpin mampu menempatkan dirinya pada posisi yang dikuasainya; (3) mampu melaksanakan tugas seperti yang dilakukan oleh Nabi Muhammad SAW yang tidak memberikan posisi kepada Abu Zarr yang terkenal adil, namun dikhawatirkan tidak dapat menjalankan tugas- 
Devi Paramitha - Kajian Tematis Al-Qur'an dan Hadits Tentang Kepemimpinan

tugasnya di lapangan; (4) kepemimpinan yang sesuai dengan aspirasi rakyat dan (5) merupakan hasil musyawarah 


\section{DAFTAR PUSTAKA}

Al-Banjari, Rachmat Ramadhana. 2008. Prophetic Leadership. Yogyakarta: DIVA Press.

Al-Bukhari, Abu 'Abdillah Muhammad ibn Isma'il. 1987. Sahih alBukhari Juz II. Cet. III; Beirut: Dar Ibn Kasir.

Al-Galayaini, Mustafa. T.th. 'Izah al-Nasyiin: Kitab Akhlak, wa Adab wa 'Ijtima'i. Bairut: Salim ibn Saud Nabhan.

Al-Hajjaj, Muslim ibn. 2001. Muqaddimah Sahih Muslim bi Syarh alNawawi Juz VI. Cet. I; Kairo: al-Maktabah al-Saqafi.

Al-Manawi, Muhammad 'Abd Rauf. 1994. Faid al-Qadir Juz I. Cet. I; Bairut: Dar al-Kutub al-'Ilmiyah

Al-Manawi, Muhammad 'Abd Rauf. 1988. al-Taisr bi Syarh al-Jami' alSagir Juz I. Cet. III; Riyad: Dar al-Nasyr

Al-Misri, Muhammad ibn Mukrim ibn Manzur. T.th. Lisan al-'Arab Juz IX. Beirut: Dar Sadir

Al-Nawawi, Abu Zakariya Yahya ibn Syaraf. 1392. Syarh Sahih Muslim Juz XII. Cet. II; Beirut: Dar Ihya' al-Turas al-'Arabi

Al-Shabuni, Muhammad Ali. 1999. Shafwah al-Tafsir: Tafsir lil al-Qur'an al-Karim Jilid I. Jakarta: Dar al-Kutub al-Islamiyyah

Al-Syaibani, Abu 'Abdillah Ahmad ibn Muhammad ibn Hambal. 1998. Musnad Ahmad Juz. III. Cet. I; Bairut: 'Alam al-Kutub

Al-Qardawi, Yusuf. 2000. Kayfa Nata'amal ma'a al-Sunnah. Cairo: Dar al-Syuruq, 2000

Baharuddin \& Umiarso. 2012. Kepemimpinan Pendidikan Islam. Jogjakarta: Ar-Ruzz Media

Fakih, Aunur Rahim, dkk. 2001. Kepemimpinan Islam. Yogyakarta: UII Press 
Kartini, Kartono. 1998. Pemimpin dan Kepemimpinan. Cet. VIII, Jakarta: PT Raja Grafindo

Tim Penterjemah. 2007. Al-Quran Al-Karim dan Terjemah Bahasa Indonesia. Kudus: Menara Kudus.

Rivai dan Arifin, Veithzal. 2009. Islamic Leadership. Jakarta: Bumi Aksara

Salim, Abd. Muin. 2004. Konsepsi Kekuasaan Politik dalam al-Qur'an. Jakarta: Raja Grafindo Persada

Shihab, M. Quraish. Tafsir Al-Mishbah vol.1.

Tasmara, Toto. Spiritual Centered Leadership.

Zakariyya, Abi al-Husain Ahmad Ibn Faris. 1989. Mu'jam Maqayis alLughah Juz II. Dar al-Fikr. 
Devi Paramitha - Kajian Tematis Al-Qur'an dan Hadits Tentang Kepemimpinan

J-PAI : Jurnal Pendidikan Agama Islam

Vol. 3 No. 1 Juli-Desember 2016 